\title{
A general convergence theorem for multiple-set split feasibility problem in Hilbert spaces
}

\author{
AbDul RAHIM KHAN ${ }^{1}$, MUjAHID ABBAS ${ }^{2}$ and YEKINI SHEHU ${ }^{3}$
}

\section{ABSTRACT.}

We establish strong convergence result of split feasibility problem for a family of quasi-nonexpansive multi-valued mappings and a total asymptotically strict pseudo-contractive mapping in infinite dimensional Hilbert spaces.

Acknowledgement. The authors A. R. Khan and M. Abbas are grateful to King Fahd University of Petroleum and Minerals for supporting research project IN 121037.

\section{REFERENCES}

[1] Alber, Y., Espinola, R. and Lorenzo, P., Strongly convergent approximations to fixed points of total asymptotically nonexpansive mappings, Acta Math. Sin. (Engl. Ser), 24 (2008), No. 6, 1005-1022

[2] Byrne, C., Iterative oblique projection onto convex sets and the split feasibility problem, Inverse Problems, 18 (2002), No. 2, 441-453

[3] Byrne, C., A unified treatment of some iterative algorithms in signal processing and image reconstruction, Inverse Problems, 20 (2004), No. 1, 103-120

[4] Ceng, L. C., Ansari, Q. H., and Yao, J. C., An extragradient method for solving split feasibility and fixed point problems, Comput. Math. Appl., 64 (2012), 633-642

[5] Censor, Y. and Elfving, T., A multiprojection algorithm using Bregman projections in a product space, Numer. Algorithms, 8 (1994), 221-239

[6] Censor, Y., Elfving, T., Kopf, N. and Bortfeld, T., The multiple-sets split feasibility problem and its applications, Inverse Problem, 21 (2005), 2071-2084

[7] Censor, Y., Motova, X. A. and Segal, A., Pertured projections and subgradient projections for the multiple-setssplit feasibility problem, J. Math. Anal. Appl., 327 (2007), 1244-1256

[8] Censor, Y. and Segal, A., The split common fixed point problem for directed operators, J. Convex Anal., 16 (2009), $587-600$

[9] Chang, S. S., Joseph Lee, H. W., Chan, C. K., Wang, L. and Qin, L. J., Split feasibility problem for quasinonexpansive multi-valued mappings and total asymptotically strict pseudo-contractive mapping, Appl. Math. Comput., 219 (2013), 10416-10424

[10] Chang, S. S., Kim, J. K. and Wang, X. R., Modified block iterative algorithm for solving convex feasibility problems in Banach spaces, J. Inequal. Appl., 14 (2010), doi:10.1155/2010/86968

[11] Maruster, S. and Popirlan, C., On the Mann-type iteration and the convex feasibility problem, J. Comput. Appl. Math., 212, (2008), 390-396

[12] Masad, E. and Reich, S., A note on the multiple-set split feasibility problem in Hilbert spaces, J. Nonlinear Convex Anal., 8 (2007), 367-371

[13] Moudafi, A., The split common fixed-point problem for demicontractive mappings, Inverse Problems, 26 (2010), $587-600$

[14] Xu, H. K., A variable Krasnosel'skii-Mann algorithm and the multiple-set split feasibility problem, Inverse Problems, 22, (2006), 2021-2034

[15] Xu, H. K., Iterative algorithm for nonlinear operators, J. London Math. Soc, 66 (2002), 1-17

Received: 01.09.2014; In revised form: 13.01.2015; Accepted: 15.01.2015

2010 Mathematics Subject Classification. 47H06, 47H09, 47J05, 47J25.

Key words and phrases. Total asymptotically strict pseudocontractive mapping, single-valued (multi-valued) quasi-nonexpansive mapping, split common fixed-point problems, strong convergence, Hilbert space.

Corresponding author: Abdul Rahim Khan; arahim@kfupm.edu.sa 
[16] Yang, Q., The relaxed CQ algorithm solving the split feasibility problem, Inverse Problems, 20 (2004), 1261-1266

[17] Yang, Q. and Zhao, J., Generalized KM theorems and their applications, Inverse Problems, 22 (2006), 83-844

[18] Yang, L., Chang, S. S., Cho, Y. J. and Kim, J. K., Multiple-set split feasibility problems for total asymptotically strict pseudocontractions mappings, Fixed Point Theory Appl., 2011 (77) (2011), http://dx.doi.org/10 1186/11871812-2011-77

${ }^{1}$ Department of Mathematics and Statistics

King Fahd University of Petroleum and Minerals

DHAHRAN, 31261, SAUDI ARABIA

E-mail address: arahimekfupm.edu.sa

2 Department of Mathematics and Applied Mathematics

University of Pretoria, Pretoria, SOUTH Africa

E-mail address: mujahid.abbas@up.ac.za

3 Department of Mathematics

UNIVERSITY OF NigERIA, NSUKKA, NigERIA

E-mail address: deltanougt2006@yahoo.com 